\title{
PORTUGAL AND SOUTH AFRICA: CLOSE ALLIES OR UNWILLING PARTNERS IN SOUTHERN AFRICA DURING THE COLD WAR?
}

\author{
Paulo Correia, Department of Historical Studies,
}

with Prof Grietjie Verhoef, Department of Accountancy,

University of Johannesburg

\begin{abstract}
The popular perception of the existence of a straightforward alliance between Portugal and South Africa as a result of the growing efficacy of African nationalist groups during the 1960s and early 1970s has never been seriously questioned. However, new research into recently declassified documents from the Portuguese military archives and an extensive overview of the Portuguese and South African diplomatic records from that period provide a different perception of what was certainly a complex interaction between the two countries. It should be noted that, although the two countries viewed their close interaction as mutually beneficial, the existing political differences effectively prevented the creation of an open strategic alliance that would have had a greater deterrence value instead of the secretive tactical approach that was used by both sides to resolve immediate security threats. In addition, South African support for Portugal's long, difficult and costly counterinsurgency effort in three different operational theatres in Africa - Angola, Mozambique and Guinea Bissau - was not really decisive since such support was never provided on a significant scale.
\end{abstract}

\section{A brief analysis of South African-Portuguese relations before the 1960s}

From an early period, relations between the Union of South Africa and Portugal were strongly influenced by events that took place in the international arena. Moreover, Portuguese perceptions of its closest neighbours in Africa were based on an acute awareness of the United Kingdom's dominant position on the African continent. Since the 1830s, tension had been building up between Portugal and the United Kingdom regarding colonial matters. On the Portuguese side, many blamed the United Kingdom for the loss of territory in India and the signing of trade agreements that did not help the development of Portuguese industry as well as the 
events that led to Brazil's independence. ${ }^{1}$ The existing tension and differences regarding the acquisition and possession of colonial territories in Africa culminated in the British Ultimatum of $1890,{ }^{2}$ a development that had a profound political impact in Portugal.

The Portuguese viewed the creation of the Union of South Africa as an affirmation of Britain's interests in Southern Africa. In addition, there were other events that strengthened Portuguese perceptions about the Union's probable intentions towards Portugal's African territories. During the First World War, Jan Smuts had formulated a secret memorandum that propagated the idea of the incorporation of part of the Portuguese territories in Africa into the Union of South Africa. ${ }^{3}$ Portuguese fears of possible expansionism on the part of the Union were clearly expressed by Norton de Matos who was Angola's Governor General from 1912 until 1915 and Angola's High Commissioner from 1921 until 1923. Matos believed that the objectives of the regional policies of the Union were territorial expansion and the creation of a United States of South Africa. ${ }^{4} \mathrm{He}$ also believed that the Afrikaners were willing to extend their influence in the African continent as far as the equator. ${ }^{5}$

In addition to the concerns about the possible territorial expansion of the Union in Southern Africa, senior Portuguese officials also expressed scepticism when confronted with explanations referring to the Union's segregation policies. During a visit to the Union in 1922, the Portuguese High Commissioner in Mozambique, Dr Manuel de Brito Camacho, expressed the view that the strict segregation policy that was followed in the Union would not succeed in the long term since the black

\footnotetext{
${ }^{1}$ R. Ramos, A Segunda Fundação (1890-1926). História de Portugal. Direcção de José Mattoso. Sexto Volume. Editorial Estampa. Lisboa 2000, p.40. In addition, to have a better perspective of Britain's interference and meddling in Brazil's independence process see V. Alexandre, Velho Brasil Novas Áfricas - Portugal e o Império (1808-1975). Biblioteca das Ciências dos Homem. Edições Afrontamento. Santa Maria da Feira, 2000, pp.35-145.

${ }^{2}$ Ibid. pp 39-40. For additional details on this matter see Eric Axelson Portugal and the Scramble for Africa 1875 - 1891, Witwatersrand University Press, 1967, pp.201297 as well as Robert I. Rotberg, The Founder - Cecil Rhodes and the Pursuit of Power. With the collaboration of Miles F. Shore. Jonathan Ball Publishers, Johannesburg and Cape Town, 2002, pp.288-319.

3 S.E. Katzenellenbogen, South Africa and Southern Mozambique - Labour, Railways and Trade in the Making of a Relationship. Manchester University Press. Manchester, 1982, pp.121-124.

${ }^{4}$ N. Mattos, Memórias e Trabalhos da Minha Vida. Volume II. Editora Marítimo Colonial, Lda. Lisboa 1944, p.184 and p.227.

${ }^{5}$ Ibid. p. 184 .
} 
population would always be substantially larger than the white population. ${ }^{6}$ The Union's black population would gradually become more educated and developed and it would increasingly reject the colour bar. ${ }^{7}$

During the next few decades, prominent Portuguese officials continued to criticise the Union's racial policies. During the 1950s, Professor Silva Cunha from the Portuguese Higher Institute of Overseas Studies emphasised that the Union's racial policies were profoundly unjust and illogical. ${ }^{8} \mathrm{He}$ believed that it was not possible to prevent the interaction between two racial groups, especially economic interaction. ${ }^{9}$ Professor Silva Cunha became Deputy Secretary of State for Overseas Administration in 1962 and Minister of the Overseas Provinces in 1965, a position that he retained until 1973 .

Despite Portuguese concerns about the Union's possible territorial ambitions in Southern Africa - which were expressed quite clearly after the First World War - as well as irreconcilable approaches to race relations, the two sides managed to reach agreements in the economic sphere quite early. One of the success stories was the construction of the railway line that linked Lourenço Marques to the mining towns in the Transvaal. ${ }^{10}$ Another factor that brought the two sides together was the use of Mozambican labourers in the Kimberley diamond mines, which started soon after the 1870s. ${ }^{11}$ The First and Second World Wars also had an impact on the relationship between the two countries. Both Portugal and South Africa acknowledged the need to maintain a policy of good neighbourliness in order to safeguard their respective security interests.

Despite the apparent willingness to maintain a policy of good neighbourliness during and after the Second World War, there were substantial differences between the two sides regarding possible tighter cooperation in the defence sphere. Portugal participated in the African Defence Facilities Conference, which was held in Nairobi in August 1951. In addition to the Portuguese delegates, the other delegates came from Belgium, Ethiopia, France, Italy, Southern Rhodesia as well as the United

\footnotetext{
${ }^{6}$ B. Camacho, Gente Bóer - Aspectos D'Africa. Livraria Editora Guimarães. Lisboa 1930, pp.28-227.

${ }^{7}$ Ibid.

${ }^{8}$ S. Cunha, Aspectos dos Movimentos Associativos na África Negra. Junta de Investigações do Ultramar, Centro de Estudos Políticos e Sociais. № 8. Lisboa 1958, pp.40-41.

${ }_{9}$ Ibid.

${ }^{10}$ M. Newitt, Portugal in Africa - The Last Hundred Years. C. Hurst \& Co. London 1981, pp.34-38.

${ }^{11}$ Ibid.p.38.
} 
Kingdom and South Africa. ${ }^{12}$ The aim of the conference was to secure an agreement "on the facilities that would be required for the movement of troops and military supplies on the lines of communication between the South of Africa and the Middle East in time of war or emergency". ${ }^{13}$ A secret report written to the Union's Department of External Affairs at the end of the Nairobi Conference in August 1951 describes Portuguese attitudes during the negotiations on possible defence arrangements on the African continent. Although there was a willingness to cooperate, rigid instructions from Lisbon tended to hamper the process. ${ }^{14}$ Moreover, the Portuguese "were extremely sensitive in regard to any proposals affecting their national sovereignty and there was evidence of their familiar suspicions of the ultimate motives and intentions of South Africa". ${ }^{15}$

\section{The complex South African-Portuguese interaction during the 1960s}

The anti-Portuguese uprising that started in northern Angola in 1961 took both the Portuguese and the South African authorities by surprise. The scale of the violence and the high number of deaths caused serious concern in both countries. ${ }^{16}$ From a Portuguese perspective, the main drawback was the limited strength of the Portuguese Armed Forces and Portugal's limited economic and financial resources. Moreover, the size of Portugal's African territories made it very difficult to coordinate logistics, especially after insurgencies broke out in Mozambique and Guinea Bissau in addition to Angola. At the end of 1961, the Portuguese also had to deal with the loss of Goa when 45000 Indian troops attacked and overwhelmed the 3500 Portuguese troops who had been deployed in that Portuguese-held territory. ${ }^{17}$

In the meantime, the initial South African response was that Portugal would not be able to withstand the attacks against its presence in Africa. In April 1961, the

${ }^{12}$ National Archives and Records Service of South Africa, NARS, BLB, Box 5, 16/10/1 Vol I, International Cooperation in Africa: Secret telegram from Secretary for External Affairs, Pretoria - High Commissioner, London, 6 July 1951.

${ }^{13}$ Ibid.

${ }^{14}$ NARS, BSB, Box 21, S.41, Annexure Jacket I, Top Secret: Secret report on African Defence Facilities Conference written in Nairobi, 31 August 1951.

${ }^{15}$ Ibid.

${ }^{16}$ M.F. Rollo, Dicionário de História do Estado Novo. Volume I. A-L. Direcção de Fernando Rosas e J.M. Brandão de Brito. Bertrand Editora. Venda Nova 1996, p.413 and A. Afonso, C.M. Gomes, Guerra Colonial. Nova Força, De 21 Setembro 1997 a 13 Setembro 1998, p.29. Also see W.S. van der Waals, Portugal's War in Angola, 1961-1974. Ashanti Publishing, First Edition, Rivonia, 1993, p.58.

${ }^{17}$ C.A. Morais, A Queda da Índia Portuguesa - Crónica da Invasão e Cativeiro. Histórias de Portugal, Editorial Estampa, 3 Edição, 1999, pp.56-92 as well as pp.193-195. 
South African Consul General in Luanda, CBH Fincham, expressed the view that the Portuguese military was ill equipped to deal with the rebellion in northern Angola since the insurgents were able to attack small towns with impunity. ${ }^{18}$ Fincham was convinced that Angola would become an independent country within one or two years since the Portuguese government in Lisbon seemed unable to come up with any innovative solution to resolve Angola's problems. ${ }^{19}$ South African newspapers also noted the success of the Indian invasion of Goa and its potential impact on the African continent. In December 1961, an article in the Rand Daily Mail predicted the intensification of violent opposition against Portugal in Africa as a result of the success of the Indian invasion of Goa. ${ }^{20}$ Earlier in that same year, The Star indicated that the average South African was perplexed to see Portugal - the poorest of the European colonial powers - "marshalling all her scant metropolitan resources" for the defence of Angola through the force of arms. ${ }^{21}$

While the South Africans had doubts about Portugal's ability to remain in Africa, the Portuguese authorities were not keen to be lumped together with South Africa - especially in the international arena - because of South Africa's racial policies. In November 1962, the Portuguese Foreign Affairs Minister, Franco Nogueira, told South Africa's Sunday Times that there were some "basic differences" between South Africa and Portugal. ${ }^{22}$ Portugal viewed South Africa's apartheid policy as "morally wrong and politically dangerous" while South Africa viewed Portugal's racial policy "as morally dangerous and politically wrong". Nogueira rejected the possibility of a military agreement between Portugal and South Africa because "whatever may happen in Angola, in Lisbon's view, the moral condemnation of having to accept aid from South Africa would be too high a price to pay". ${ }^{23}$ He later defended his views by telling the South African Ambassador in Lisbon that he had told the Sunday Times that relations between South Africa and Portugal were excellent but that "even good neighbours sometimes had problems which with goodwill could easily be solved". ${ }^{24}$

18 NARS, Buitelandse Sake, BTS, Box 1/22/1, Vol 2. Angola: Political Situation/Developments. B:02.02.61/E: 30.04.61: Secret letter from South African Consul General, Luanda - Secretary for External Affairs, Pretoria, 5 April 1961.

${ }^{19}$ Ibid.

${ }^{20}$ Rand Daily Mail, 27 December 1961.

${ }^{21}$ The Star, 29 May 1961.

${ }^{22}$ Sunday Times, 25 November 1962.

${ }^{23}$ Ibid.

${ }^{24}$ NARS, BLB, Box 8, Press Propaganda and Publicity as well as Radio and Television P.5/1: Confidential letter from South African Ambassador, Lisbon - 
A journalist from South Africa's Rand Daily Mail who visited Angola and Mozambique in 1963 explained that senior Portuguese officials were very anxious to dismiss any suggestions that they would subscribe to policies that promoted racial discrimination. ${ }^{25}$ An alliance between Portugal and South Africa was not really viable since it would attract the attention of the United Nations as well as the possibility of a "technical state of war" with independent African States, which would view such an alliance as an affront. ${ }^{26}$

Despite obvious differences in the political sphere and the avoidance of any formal alliance, the two countries continued to make efforts to promote informal cooperation in a number of areas. In September 1962, the two countries agreed to renegotiate the Mozambique Convention on rail traffic between South Africa and the port of Lourenço Marques in Mozambique. ${ }^{27}$ In May 1963, South Africa and Portugal also signed an air agreement in Lisbon that stipulated the routes and the number of passengers that could embark and disembark at the respective airports in the territories of both countries. ${ }^{28}$ At the end of 1964, the two countries reached an agreement on the joint utilisation of the waters of the Kunene River - which would benefit the population of Southern Angola and South West Africa. ${ }^{29}$ In March 1965, it was disclosed that South Africa would grant a loan of R5.75 million to Angola's Matala hydro-electrical project, while Portugal had agreed to provide 90 million kilowatt hours of electricity annually to South West Africa at a cost of 0.5 cents per unit. $^{30}$

One area that received particular attention from both sides was the exchange of intelligence about persons who were considered to be a security risk. However, such cooperation did not take place overnight. The initial groundwork for the exchange of intelligence between the two countries had already begun in the 1950s. An inspector

Secretary for Foreign Affairs, Pretoria, 28 November 1962. The South African Ambassador was A.H.H. Mertsch.

${ }^{25}$ Rand Daily Mail, 12 July 1963. The journalist was Donald Prosser.

${ }^{26}$ Ibid.

${ }^{27}$ NARS, BTS, Box 10/5/31/2, Vol 2, Revision of Mozambique Convention: See Portuguese document written on 25 September 1962. For additional details see NARS, BTS, Box 10/5/31/2, Vol 2, Revision of Mozambique Convention: Secret document, Mozambique Convention - Report on discussions in Lisbon $17^{\text {th }}$ to $25^{\text {th }}$ September 1962 regarding revision of Convention.

${ }_{28}$ Portugal's Ministry of Foreign Affairs, Arquivo Histórico-Diplomático (AHD), PAA 1132: See 'Information Note N ${ }^{\mathrm{o}}$ 13-63', 10 May 1963.

${ }^{29}$ AHD, PAA 1132: See document "Circular dos Serviços de Informação N ${ }^{\circ}$ 26", 14 October 1964.

${ }^{30}$ Rand Daily Mail, 20 March, 1965. Also see p.25 of the Angola-Mozambique Supplement of South Africa's Financial Mail, 15 August 1969. 
from Portugal's Polícia Internacional de Defesa do Estado (PIDE), António Neves Graça, visited the Union of South Africa in December 1954 to establish contacts that could facilitate the exchange of information between the security services of both countries. ${ }^{31}$ However, cooperation between the Portuguese and South African security services did not really develop during the 1950s. In 1960, a secret Portuguese document mentioned that a Colonel Prinsloo of the South African police's Security Branch had informed the Portuguese military attaché at the Portuguese Embassy in South Africa that cooperation between the security services from both countries was not very effective. ${ }^{32}$ The document explains that the South Africans were keen to expand contacts with the Portuguese security services in both Angola and Mozambique. In June 1962, the Portuguese Consulate in Windhoek informed the Portuguese Ministry of Foreign Affairs in Lisbon of the interest expressed by the Commander of the South West African Police in establishing links with PIDE in Angola. ${ }^{33}$ In July the same year, the PIDE structures in Angola confirmed the establishment of formal links after a meeting in South West Africa. ${ }^{34}$

The establishment of formal channels to exchange intelligence was not an easy or straightforward procedure. Portuguese suspicions of South African intentions in Angola and Mozambique were clearly spelt out in a document from the Office of Political Affairs of the Portuguese Overseas Ministry of February 1962. The secret document rejected a proposal that called for the deployment of a South African military attaché in Angola and another one in Mozambique. ${ }^{35}$ The request was made on 2 November 1961 in an Aide Memoir by the South African Embassy in Lisbon to the Portuguese authorities. ${ }^{36}$ The Portuguese Overseas Ministry regarded the exchange of military information between the Portuguese and South African military establishments as not really desirable. The following reasons were offered:

${ }^{31}$ AHD, PAA 1139: Confidential letter addressed to the Portuguese Ambassador in Cape Town, General Adolfo do Amaral Abranches Pinto, 17 February 1955. Also see PAA 1139, Report from Inspector António Neves Graça, 24 January 1955.

${ }^{32}$ AHD, PAA 1139: Secret document addressed to the Portuguese Deputy Secretary for National Defence, 11 October 1960.

33 AHD, GNP-MU, Arm 1. Gav.3 M339: Secret letter addressed to the Governor General of Angola, 23 June 1962. The document mentions that a Colonel Botha was the Commander of South West Africa's police force.

34 AHD, GNP-MU, Arm. 1. Gav.3 M339: Secret PIDE letter addressed to the Portuguese Minister of Overseas Territories, 27 July 1962. The meeting took place in the town of Tsumeb.

35 AHD, Gabinete dos Negócios Políticos do ex-Ministério do Ultramar, GNP-UM, Arm.11, Gav.2, M.313: Secret document 'Informação N 295', 7 February 1962.

${ }^{36}$ AHD, GNP-UM, Arm.11, Gav.2, M.313: Aide Memoir, Lisbon 2 November 1961. 
- There were still some South African sectors that displayed what the document described as 'old attitudes' towards the African territories under Portuguese control. The Office of Political Affairs of the Portuguese Overseas Ministry claimed that it was aware of 'certain South African projects', which would be implemented should events on the ground force the Portuguese authorities to lose control of Angola and Mozambique. There was the perception that, if the Portuguese authorities had lost control of the situation in the two territories, the South Africans could possibly take over some parts of Angola and Mozambique.

- The white population in Angola and Mozambique was favourably disposed towards South Africa at a time when there were doubts about Portugal's capacity to deal with the ongoing rebellion in Angola. The deployment of South African military attachés could result in what the document called 'undesirable developments'. This implied that the Portuguese authorities suspected that the white population in Angola and Mozambique, would be more amenable towards South Africa if Portugal, was unable to guarantee the security of its African possessions.

- The development of a closer relationship with South Africa - especially on matters of 'mutual security' - should not be in the shape of a formal arrangement because African nationalist propaganda would be directed against Portugal as a result of South Africa's racial policy. Cooperation between Portugal and South Africa had to be less visible in order to avoid or reduce the potential of criticism.

- Although defence cooperation between Portugal and South Africa would boost the confidence of the white population in Angola and Mozambique, it could have the opposite effect on the black population. This could jeopardise Portuguese efforts to improve relations between different races on the basis of non-discrimination. ${ }^{37}$

The Portuguese Overseas Ministry emphasised that it was necessary to convince the South Africans that their security would not be affected by events in Angola and Mozambique. It was also advisable to keep the South Africans "reasonably informed" of developments in the two territories. It would be best if South African military attachés were deployed in the Portuguese capital, Lisbon. One of the attachés would be allowed to travel to Angola on long trips, provided he moved

${ }^{37}$ AHD, GNP-UM, Arm.11, Gav.2, M.313: Secret document "Informação N ${ }^{\mathrm{o}} 295$ ", 7 February 1962. 
around under Portuguese supervision. In Mozambique, such visits would have to be less frequent and of short duration. ${ }^{38}$

Towards the end of 1961, PIDE had noted that certain unidentified South African sectors wanted to see the incorporation of Lourenço Marques into South Africa. ${ }^{39}$ Portuguese suspicions about South African intentions were based on a report in The Star of October 1961. The leader of the Transvaal branch of the United Party, Henry Tucker, mentioned the possibility of the incorporation of Lourenço Marques into South Africa. Tucker insisted that, in addition to Lourenço Marques, South West Africa and the territories of Southern Rhodesia and Swaziland as well as the Bechuanaland Protectorates and Basutoland should all become part of what he called a "greater Republic of South Africa". ${ }^{40}$ Despite the fact that these were not official South African government statements, they still raised concerns in Portugal.

Although senior Portuguese officials might have had doubts about the political impact of a closer relationship between the two countries, the two sides began to interact more closely in the military sphere. When the South African Minister of Defence, JJ Fouché, visited Lisbon in July 1961, the two sides discussed possible cooperation between the South African Air Force (SAAF) and the Portuguese Air Force (FAP). ${ }^{41}$ In December 1961, the Portuguese military and air attaché in Pretoria, Colonel A Silva Viana, suggested the creation of effective telecommunication links between the military authorities of both countries. ${ }^{42}$ In April 1962, the South African Secretary for Foreign Affairs, GP Jooste, approved the request to establish a military radio telecommunications service between Portugal and South Africa. ${ }^{43}$ In September 1963, the South African Prime Minister, HF Verwoerd, wrote to his counterpart, António de Oliveira Salazar, stating that

38 Ibid.

39 AHD, GNP-MU, Arm.1, Gav.3, M.350 (1951/1963): PIDE document addressed to the Portuguese Overseas Ministry, 22 December 1961.

${ }^{40}$ The Star, 5 October 1961.

41 NARS, BTS, Box 74/29 (F1), Burgerlike Lugvaart en militêre verbindings. B: 02.10.61/E: 12.11.64. Letter from Portuguese army and air attaché in South Africa, Pretoria, 2 October 1961. The discussion focused on the training of SAAF paratroop instructors by the FAP as well as the possible provision of an aircraft maintenance service and the supply of aircraft ammunition by South Africa.

${ }^{42}$ NARS, BTS, Box 74/29 (F1), Burgerlike Lugvaart en militêre verbindings. Secret memorandum from Colonel A Silva Viana, Pretoria, 14 December 1961. The memorandum is addressed to the Deputy Commandant General of the South African Defence Force.

43 NARS, BTS, Box 74/29 (F1), Burgerlike Lugvaart en militêre verbindings. B: 02.10.61/E: 12.11.64: Top secret letter from Secretary for Foreign Affairs Secretary for Defence, Cape Town, 9 April 1962. 
South Africa was glad to have provided "material assistance in the shape of military equipment during the Angolan rebellion last year to the extent that our resources and supplies permitted" ${ }^{44}$ It is clear that both sides began to view closer cooperation in the military sphere as mutually advantageous due to the expansion of African nationalism in the African continent. In November 1963, Angola's intelligence structures began to receive information from the South African police in South West Africa about SWAPO members involved in pulling down the border fence between the two territories. ${ }^{45}$ At the same time, South Africa appointed military officers to the position of vice consul at the South African Consulates in Angola and Mozambique. The aim was to create a permanent connection to exchange intelligence. ${ }^{46}$ Moreover, the Portuguese gradually began to display greater willingness to obtain South African logistical support. In September 1964, the Portuguese military authorities in Angola felt sufficiently at ease with the South African Consul General in Luanda, EM Malone, to request spare parts for their Alouette III helicopters directly. ${ }^{47}$ By February 1965, Malone realised that the Portuguese viewed the war in Angola as a joint effort against subversion, and South Africa was thus expected to play her part in this effort. ${ }^{48}$

At a more senior level, the issue of closer military links between the two countries was discussed when South Africa's Defence Minister, PW Botha, visited Portugal in April 1967. ${ }^{49}$ PW Botha's views were recorded in a secret report of the Portuguese Foreign Affairs Ministry. ${ }^{50}$ According to the report, the South African Defence Minister told his Portuguese hosts that it was not necessary for the two countries to agree on a formal military alliance but that senior military officers from both countries should conduct high-level talks about the common problem of how to

\footnotetext{
${ }^{44}$ AHD, PAA 1132: Letter from HF Verwoerd to António de Oliveira Salazar, 17 September 1963.

45 AHD, PAA 58: Política Externa e Interna da África do Sul. Acção desenvolvida pela SWAPO: Secret document Informação $\mathrm{N}^{\circ}$ 606/SCCI/Assunto: Actividades Terroristas da SWAPO - South West African Peoples Organization', 2 November 1963.

${ }^{46}$ W.S. van der Waals, Portugal's War in Angola, 1961-1974, p.134.

${ }^{47}$ NARS, BTS, Box 1/22/5, Vol 2, Angola: Defence. B: 05.04.61/E: 29.11.67: Secret letter from South African Consul General, Luanda - Secretary for Foreign Affairs, Pretoria, 14 September 1964.

${ }^{48}$ NARS, BTS, Box 1/22/5, Vol 2. Angola: Defence. B: 05.04.61/E: 29.11.67. Secret letter from South African Consul General, Luanda - Secretary for Foreign Affairs, Pretoria, 9 February 1965.

${ }^{49}$ The Cape Argus, 8 April, 1967 and The Star, 7 April, 1967.

50 AHD, PAA 1132: Secret document Portuguese Ministry of Foreign Affairs, "Ministério dos Negócios Estrangeiros - Relato de Conversa", 07.04.67.
} 
defend Southern Africa. ${ }^{51}$ PW Botha indicated that South Africa was prepared to make available any type of military supplies if it was feasible. The Portuguese would have to pay a "nominal price" for these supplies. This included military aircraft if there was a request for the acquisition of such aircraft. ${ }^{52}$ Soon after PW Botha's visit, the General Officer Commanding the South African Defence Force's Joint Combat Forces, General CA Fraser, told the Portuguese Ambassador in South Africa, Francisco Menezes Rosa, that the Portuguese and the South African authorities should consider the possibility of holding joint strategic meetings. ${ }^{53}$ According to Ambassador Rosa, General Fraser had made it clear that the two countries would have to cooperate more closely when it came to defence matters. ${ }^{54}$ These comments and PW Botha's visit to Portugal were a clear indication that the South Africans wanted to accelerate cooperation with the Portuguese authorities in the military and security spheres.

In February 1968, South Africa's Defence Minister, PW Botha, told his Portuguese counterpart, General Gomes de Araújo, that the South African government had agreed to grant the Portuguese Armed Forces in Angola five Alouette III helicopters and 33 Panhard armoured vehicles as well as 283 TR/28C radio sets. ${ }^{55}$ The equipment would be made available on a "free loan basis". ${ }^{56}$ In May 1968, PW Botha informed General Araújo that South Africa would provide spare parts for the five Alouette III helicopters and the 33 Panhard armoured vehicles. ${ }^{57}$ South Africa would also provide air support in the shape of eight Alouette helicopters and four Cessna aircraft, which could be used during Portuguese military operations in eastern and south-eastern Angola. ${ }^{58}$ The eight

\footnotetext{
${ }^{51}$ Ibid.

${ }^{52}$ Ibid.

${ }^{53}$ AHD, PAA 1132: Secret letter Director General of the Portuguese Ministry of Foreign Affairs - Portuguese Deputy Secretary of National Defence, 23 May 1967. The letter indicates that CA Fraser had the rank of 'General'. However, a report in The Star dated the 18 December 1967 refers to CA Fraser as 'Lieutenant General'. ${ }^{54}$ Ibid.

${ }^{55}$ Portuguese Military Archives, Arquivo de Defesa Nacional (ADN), São Julião da Barra Fort, Oeiras, File 2732.2: Letter South African Defence Minister, Cape Town - Portuguese Defence Minister, Lisbon, 16 February 1968.

${ }^{56}$ Ibid. The French government gave Portugal permission to use the French manufactured helicopters and armoured vehicles. For more details on this matter see ADN, File 2732,2: Secret letter Portuguese Defence Minister, Lisbon - South African Defence Minister, Cape Town, 25 March 1968.

${ }^{57}$ ADN, File 2732.2: Top-secret secret letter, South African Defence Minister, Cape Town - Portuguese Defence Minister, Lisbon, 17 May 1968.

${ }^{58}$ Ibid.
} 
61

Alouette helicopters and the four Cessna aircraft would be permanently stationed in South West Africa. When the aircraft were operating in Angola, the South African pilots and the respective crew would use Portuguese uniforms without insignia or badges identifying military rank. Moreover, any South African aircraft operating in Angola would be marked with Portuguese Air Force markings. The aim of these measures was to maintain the secrecy of any operations that included the presence of South African aircraft and South African air crews in Angola. The Portuguese would have to provide fuel and lubricants when South African aircraft where operating in Angola. ${ }^{59}$ The Portuguese would also have to pay for any ammunition, explosives, medicines, and spare parts that were made available by the South Africans. ${ }^{60}$ In May 1968, the South African authorities established a permanent air force structure in Rundu in the Caprivi Strip - the $1^{\text {st }}$ Air Component - in order to coordinate air support for both the Portuguese military in south-eastern Angola and the South African police in South West Africa. ${ }^{61}$ A Joint Air Support Centre was also established in Cuito Cuanavale in Angola's Cuando Cubango district. It was in this centre that South African aircraft and the respective pilots and aircraft maintenance personnel as well as communications personnel could be stationed temporarily when they provided assistance to the Portuguese military forces in south-eastern Angola. ${ }^{62}$

In June 1968, the Commander-in-Chief of the Portuguese Armed Forces in Angola, General João de Almeida Viana, ordered the Portuguese military in southeastern Angola to make available the necessary cartographic materials to the South African air force structure in Rundu in order to enable the South African pilots to perform their missions over Angolan territory. ${ }^{63}$ The use of South African helicopters during operations that entailed the participation of military personnel from both countries was confined to reconnaissance flights and the transportation of security and intelligence agents in charge of collecting information as well as the evacuation of Portuguese military personnel. ${ }^{64}$ South African helicopters were also used to drop off Portuguese troops who were going to attack specific targets on the ground or to provide support to local military garrisons and to protect isolated

\footnotetext{
${ }^{59}$ Ibid.

${ }^{60}$ Ibid.

${ }^{61}$ W.S. van der Waals, Portugal's War in Angola, 1961-1974. Ashanti Publishing, First Edition, Rivonia, 1993, p.209.

${ }^{62}$ ADN, SGDN, File 4216.1: Top-secret document, "Informação N ${ }^{\circ}$ 121/RA, 24.02.1970".

${ }^{63}$ ADN, File 5696.3: Top-secret directive from Commander-in-Chief of the Portuguese Armed Forces in Angola, 14 June 1968.

${ }^{64}$ ADN, SGDN, 4216.1: Top-secret document "Informação N ${ }^{\circ}$ 121/RA,

24.02.1970".
} 
villages under attack in south-eastern Angola. Moreover, South African helicopters were used in the pursuit of groups of insurgents who were fleeing from the security forces while Portuguese aircraft provided protection for the South African aircraft operating in Angola. In addition, Portuguese aircraft were responsible for directing fire onto the assigned targets that were being attacked. ${ }^{65}$ From the perspective of the South African Defence Force, the operations in south-eastern Angola - which included the participation of both Portuguese and South African military personnel served not only to disrupt SWAPO's efforts to infiltrate South West Africa but they also enabled South African pilots and air force crews to gain combat experience in a real operational theatre. ${ }^{66}$

It is clear that from 1968 onwards, senior Portuguese military officers appeared to be more willing to accept South African support in southern Angola. In November 1968, the General Chief of Staff of the Portuguese Armed Forces, General Venâncio Augusto Deslandes, instructed the Portuguese security forces in Angola to allow the South African police to conduct rapid "hot pursuit" operations in Angolan territory if there was a need to stop groups of insurgents that might threaten South West Africa. ${ }^{67}$ The only condition was that the South African police had to inform the Portuguese military authorities about its intention to pursue insurgents in Angolan territory. Moreover, South African police units could not be stationed inside Angola and they could only operate close to the border that separated the two territories. ${ }^{68}$ Such a posture highlights the fact that, although the Portuguese authorities were prepared to allow some units of the South African police to conduct "hot pursuit" operations close to the border, they still had reservations about the presence of South African forces inside Angolan territory.

However, despite these measures SWAPO insurgents continued to move closer to South West Africa. In December 1968, General Fraser explained in a memorandum that SWAPO insurgents continued to cross over from Zambia into Angola's Rivungo and Luiana regions. ${ }^{69} \mathrm{He}$ said that, while the Portuguese had

\footnotetext{
${ }^{65}$ Ibid.

${ }^{66}$ Ibid.

${ }^{67}$ ADN, SGDN, File 4216.1: Top-secret 'verbal note' from the General Chief of Staff of the Portuguese Armed Forces, 27 November 1968.

${ }^{68}$ Ibid.

${ }^{69}$ NARS, BTS, Box 1/22/4, Vol 1. Angola: Technical Assistance Rendered by the Republic, B:17.10.61/E: 20.05.69 Top-secret Memorandum: "Non-Combat Military Aid to the Portuguese in the Cuando Cubango District of Angola", by Lieutenant General CA Fraser, 10 December 1968. The information is contained in Appendix A that is part of this memorandum, The Appendix A is titled "Situation in Angola with special reference to South East Angola: Districts of Moxico and Cuando Cubango".
} 
deployed twenty two battalions in northern Angola and six battalions in eastern Angola, they had deployed only one battalion in south-eastern Angola. ${ }^{70}$ This indicated that the Portuguese did not view the insurgent threat in south-eastern Angola in the same way as the South African authorities in South West Africa. General Fraser added the following: "from a South African standpoint the fact that the insurgents are being granted unhindered opportunity to establish sanctuaries and lines of communication within a few days march from our very borders can only be regarded as one fraught with danger to us". ${ }^{71}$ It should be pointed out, however, that the main reason why the Portuguese gave less attention to the infiltration of insurgents in south-eastern Angola was the fact that they had overextended their military capacity in Angola, Mozambique and Guinea Bissau. Furthermore, the protection of northern Angola was viewed as a priority because that is where most of Angola's largest towns - including the territory's capital - were located. General Fraser's comments indicate that, despite the secret working relationship that developed between the military establishments of both countries, there was some tension about what would be the most appropriate strategy to deal with security threats. The main source of concern for South Africa's military establishment was the infiltration of SWAPO insurgents into northern South West Africa via southeastern Angola. In the meantime, the Portuguese had to deal with several immediate threats and they could not focus their attention in one particular area - in this case south-eastern Angola - when they had to handle many other security threats in three different operational theatres.

There was also an additional source of disagreement between the sides. During the late 1960s, the Portuguese authorities hinted at the possibility of obtaining a large loan from South Africa in order to help maintain control over Portugal's possessions in Southern Africa. In December 1968, Angola's Governor General told the South African Consul General in Luanda that the Portuguese Minister of Defence in Lisbon was preparing an overall request for assistance that would be delivered to the South African government. ${ }^{72}$ According to the South African Consul General, this package would comprise military and civil components and it would replace the piecemeal presentation of requests that had hitherto "characterized the Portuguese approach". ${ }^{73}$ The Ministers of both countries first discussed the issue of additional South African assistance for Portugal's military efforts in Angola and

\footnotetext{
${ }^{70}$ Ibid.

${ }^{71}$ Ibid.

72 NARS, BTS, Box 1/22/4, Vol 1. Angola: Technical Assistance Rendered by the Republic, B: 17.10.61/E: 20.05.69: Top-secret letter South African Consul General, Luanda - Secretary for Foreign Affairs, Pretoria, 05 December 1968.

${ }^{73}$ Ibid.
} 
64

Mozambique in February $1969^{74}$ when the Portuguese Minister of Defence visited Cape Town in that same month. ${ }^{75}$ The negotiations referring to South African financial assistance continued when PW Botha visited Lisbon in March 1969. ${ }^{76}$ During the meeting in the Fort of São Julião da Barra on the outskirts of Lisbon on 24 March 1969, PW Botha indicated that his government was prepared to grant a loan to Portugal in the near future. ${ }^{77}$ This was after he had analysed the Portuguese request for financial and material aid, which he estimated to be around R130 million. ${ }^{78}$ However, PW Botha made it clear that, in order to avoid parliamentary scrutiny the total amount of the loan could not exceed R50 million. ${ }^{79}$

The next round of negotiations took place in Pretoria in May $1969 .^{80}$ The negotiations were handled by senior military delegations from both countries. During the meeting, the Portuguese were informed that the R50 million had been reduced to R25 million. ${ }^{81}$ This was because the South African government felt that it had already granted substantial concessions to the Portuguese in respect of the Cabora Bassa project in Mozambique. The head of the Portuguese delegation was the Portuguese Deputy Secretary for National Defence, General Paiva Brandão. He expressed his profound disappointment at the South African government's decision to cut the proposed loan by half since the total amount mentioned in the initial Portuguese request for financial and material aid was around R130 million, which represented Portugal's most urgent needs in the defence sector. ${ }^{82}$ General Brandão also indicated that some military equipment that had been offered by PW Botha free of charge - which was worth R11 million - was mostly old equipment that was

\footnotetext{
${ }^{74}$ AHD, PAA 1137: Cooperação Militar: Secret letter Portuguese Defence Minister - South African Defence Minister. The letter does not have a specific date but it was written soon after the Portuguese Minister of Defence, Horácio José de Sá Viana Rebelo held talks with PW Botha in Cape Town on the 11 February 1969.

${ }^{75}$ The Star, 11 February 1969.

${ }^{76}$ AHD, PAA 1137: Cooperação Militar: Top-secret document, "Relato das Conversações Havidas em S. Julião da Barra em 24 Março 69 entre suas Exas, os Ministros da Defesa da R.A.A. e de Portugal" from Portugal's General Secretariat for National Defence.

${ }^{77}$ Ibid.

${ }^{78}$ Ibid.

${ }^{79}$ Ibid.

${ }^{80}$ AHD, PAA 1137: “Cooperação Militar”: Top-secret document from Portugal's Secretariat for National Defence, which describes the meeting in Pretoria on the 8 May 1969.

${ }^{81}$ Ibid.

${ }^{82}$ Ibid.
} 
considered to be obsolete. ${ }^{83}$ It is clear that General Brandão did not view South Africa's proposal as a reasonable offer. The Portuguese military delegation held further talks with PW Botha before leaving South Africa. ${ }^{84}$ Botha told the Portuguese delegation that it had never been cast in stone that South Africa's loan would be R50 million but rather that it would not exceed R50 million in order to avoid parliamentary scrutiny. ${ }^{85}$

In a letter to his Portuguese counterpart, Botha explained South Africa's position. ${ }^{86}$ The loan would exclude obsolete military equipment to the value of R8.5 million, which would be granted free of charge. However, it would include new military equipment valued at R6.6 million that would be subtracted from the R25 million. ${ }^{87}$ The remaining R18.4 million would be payable in gold. The R25 million loan package would have to be repaid over a twenty year period and repayments would commence five years after the loan was drawn. The South African authorities would also charge an annual interest fee of $4 \% .{ }^{88}$ Botha confirmed that South Africa would grant two helicopters to the Portuguese military forces in Angola, which would serve to replace two helicopters that had been lost in Angola. However, he made it clear that no more helicopters would be made available to the Portuguese military forces in future. ${ }^{89}$

In a letter to his South African counterpart on 27 May 1969, the Portuguese Minister of Defence, General Viana Rebelo, accepted the conditions put forward by PW Botha. ${ }^{90}$ However, he indicated that he had always understood that South Africa's response to the Portuguese request for assistance would translate itself into the cession of equipment worth R11 million plus the R50 million loan package, which would be payable in gold. ${ }^{91}$ General Rebelo told PW Botha that he "became

${ }^{83}$ Ibid. An example of this obsolete equipment was several Harvard aircraft offered by the South Africans.

${ }^{84}$ AHD, PAA 1137: "Cooperação Militar": Top-secret document from Portugal's Secretariat for National Defence, which describes the meeting that took place between the Portuguese military delegation and PW Botha on the 9 May 1969.

${ }^{85}$ Ibid.

${ }^{86}$ AHD, PAA 1137: "Cooperação Militar": Top-secret letter from South African Minister of Defence, Pretoria - Portuguese Minister of Defence, Lisbon, 8 May 1969.

${ }^{87}$ Ibid.

${ }^{88}$ Ibid.

${ }^{89}$ Ibid.

90 AHD, PAA 1137: "Cooperação Militar": Top-secret letter from the Portuguese Minister of Defence, Lisbon - South African Minister of Defence, Cape Town, 27 May 1969.

${ }^{91}$ Ibid. 
surprised with the actual resolution of your Cabinet to allow only $50 \%$ of that loan because of the expenses of the Cabora Bassa project". ${ }^{92}$ He requested some changes to the repayment process of the loan, which PW Botha accepted. ${ }^{93}$

The tone of the negotiations indicated that the two sides did not fully agree on the financing of a strategy that could facilitate Portuguese efforts to contain the insurgencies in Portugal's African territories. Such a strategy was dependent on sustained financial capacity that eluded the much pressed Portuguese authorities. The disappointment expressed by senior Portuguese officials during the negotiations highlights the fact that the Portuguese authorities expected more from the South African government.

The use of secrecy and the inability to openly acknowledge Portuguese-South African cooperation

Within official governmental circles there was little support for a more open approach, which could give the public a clearer glimpse on how the two countries interacted during a difficult period of the Cold War. This was especially the case of how the Portuguese handled South African overt aid. The arduous counterinsurgency campaign that the Portuguese were forced to conduct in Mozambique - a territory that shared a common border with South Africa - soon attracted the attention of individual South Africans who wanted to alleviate the difficulties faced by Portuguese soldiers in that territory. In September 1967, a wine producer in South Africa's Cape region, Bernard Podlashuk, set up the Mozambique Fighting Soldiers' Comfort Fund, ${ }^{94}$ whose aim was to make a goodwill gesture by providing "small comforts to alleviate the fighting soldiers' endurance of terrible guerrilla warfare". ${ }^{95}$ In December 1967, at least fifteen South African aircraft took more than 3500 Christmas parcels to Portuguese soldiers who had been deployed in northern Mozambique. ${ }^{96}$ The next year, the Fund began to collect money to buy air ambulances for the Portuguese troops in Mozambique. ${ }^{97}$ Two air ambulances were handed over to the Portuguese military authorities in Lourenço Marques at the end

${ }^{92}$ Ibid.

${ }^{93}$ Ibid. The changes were that repayment of the loan should only commence at the end of the sixth year after the date on which the loan was drawn and that the $4 \%$ interest rate should be reduced to $3 \%$ per annum. Botha's reply and acceptance of these changes can be found in AHD, PAA 1137: "Cooperação Militar": Secret letter from South African Defence Minister, Cape Town - Portuguese Defence Minister, Lisbon, 18 June 1969.

${ }^{94}$ The Star, 14 September 1967.

${ }^{95}$ The Star, 25 October 1967.

${ }^{96}$ The Daily News, 13 December 1967

${ }^{97}$ The Daily News, 17 October 1968. 
of January 1969. ${ }^{98}$ Although most of the efforts carried out by individual South Africans who wanted to help Portuguese soldiers in Mozambique were generally welcomed there was also concern that South African solidarity with Portuguese war aims had become part of the public domain. This became clear at the end of September 1968 when at least twenty five specialist surgeons from Johannesburg indicated that they were willing to fly to Mozambique to help treat wounded soldiers free of charge. ${ }^{99}$ The person behind the scheme was a Johannesburg resident, Dr Hjalmar Reitz, who had been shocked to see the type of combat injuries inflicted on Portuguese soldiers in Mozambique and who disclosed that there were only 150 doctors to treat the soldiers in that territory. ${ }^{100}$

South African medical support would certainly help to alleviate the plight of many Portuguese soldiers who had been wounded during combat operations. However, a document from the Portuguese Ministry of Foreign Affairs in Lisbon dismissed any possibility of such collaboration ever taking place because of the political impact of such support. ${ }^{101}$ The document indicated that the countries that were openly hostile to Portugal in the international arena would be able to exploit the issue of overt South African medical support. This was contrary to the secret nature of the relationship that existed between the two countries in the military and security spheres. The document explained that the opponents of Portugal's presence in Africa were already making use of every opportunity to highlight existing cooperation between Portugal and South Africa in various fields. As a result, it would not be in Portugal's best interests to allow such cooperation to take place even though the Portuguese military authorities in Mozambique did not have any objections in respect of South African medical support. ${ }^{102}$

The use of secrecy became the major tool to disguise the intentions of South African and Portuguese military planners. As a result, the two parties were always concerned with the breakdown of the rules of secrecy. In April 1970, the Portuguese Embassy in Pretoria sent a detailed report to the military authorities in Lisbon describing how several American diplomats in South Africa were trying to obtain

${ }^{98}$ The Natal Mercury, 27 January 1969. The two light aircraft cost a total of R50 000. The funds to pay for the aircraft were collected in Natal and the Orange Free State.

${ }^{99}$ The Star, 30 September 1968.

${ }^{100}$ Ibid.

${ }^{101}$ AHD, PAA M.1138: “África do Sul - Dádivas e auxílio às Forças Armadas Portuguesas em Combate": Document from Director General Coelho Lopes, Lisbon - General Chief of Staff of the Portuguese Armed Forces, Lisbon, 11 November 1968.

${ }^{102}$ Ibid. 
information about the presence of South African military aircraft and South African military personnel in south-eastern Angola. The report - which was written by the Portuguese military attaché in Pretoria - emphasised that it was necessary to ensure the secrecy of the military collaboration between the two countries. ${ }^{103}$ In the meantime, in August 1972, the South African Consul General in Luanda, EM Malone, expressed concern about the fact that a South African freelance journalist, SJR McIntosh, had obtained confidential information about the presence of South African military personnel in south-eastern Angola. ${ }^{104}$

The concern that South African and Portuguese officials displayed about the disclosure of information indicated the fear of the political impact that such disclosures could have in the public arena. Portuguese diplomats, for example, were reluctant to accept the deployment of a large military mission in South Africa after the Portuguese government issued an official note indicating that a permanent Portuguese mission would be established in Pretoria at the beginning of $1974 .{ }^{105}$ The mission would comprise one general and four lower ranking officers as well as a military interpreter and a military archivist. ${ }^{106}$ The Portuguese ambassador in South Africa, Francisco Menezes Rosa, argued that the arrival of such a military contingent in Pretoria was bound to raise questions about the relationship between the two countries. ${ }^{107}$ The Portuguese Ministry of Defence referred to the new Portuguese mission in South Africa as the "Alcora Missio". ${ }^{108}$ In the recently declassified documents from Portugal's military archives, the Alcora Exercise is described as "the investigation of ways and means to establish a coordinated tripartite effort whose aim will be to counterbalance the common threat that is directed towards all the Alcora participants". ${ }^{109}$ The participant countries were

103 ADN, SGDN, File 5852.3: Report from Portuguese Embassy, Pretoria Portuguese General Secretariat for National Defence, Lisbon, 30 April 1970.

104 NARS, BTS, Box 1/22/3, Vol 3. Angola: Relations with South Africa. B: 12.06.70/E: 10.08.72: Secret letter from Consul General, Luanda - Secretary for Foreign Affairs, Pretoria, 2 August 1972.

${ }^{105}$ AHD, PAA 1131: Document signed by the Portuguese Minister of Defence and the Minister of Finance, 17 January 1974.

${ }^{106} \mathrm{Ibid}$

${ }^{107}$ AHD, PAA 1131: Secret telegram from Portuguese Ambassador, Cape Town Portuguese Ministry of Foreign Affairs, Lisbon, 31 January 1974.

${ }^{108}$ AHD, PAA 1131: Letter from the Office of the Portuguese Minister of Defence, Lisbon - Office of the Portuguese Minister of Foreign Affairs, Lisbon, 8 February 1974.

109 ADN, File 3036.2: Document "Exercício Alcora - Primeira Reunião da SubCommissão de Telecomunicações e Guerra Electrónica a realizar no periodo de 20 24 de Setembro de 1971", 17 August 1971. Very few documents mentioning the 
Portugal, South Africa and Rhodesia. The above-mentioned controversy indicates that there were differences of opinion between Portuguese diplomats and the Portuguese military. The core of the controversy was the issue of how to disguise the new military delegation so that it would not attract the attention of prying eyes.

\section{The final phase of Portuguese-South African cooperation}

Although it is difficult to make a precise assessment of the impact of South African support for the Portuguese military effort in Angola and Mozambique, it is clear that such support was by far never sufficient or broad enough to help change the course of the war in the former Portuguese territories. In 1974, the Portuguese had accumulated a total of 93 helicopters in Africa. ${ }^{110}$ The vast majority of these helicopters were Alouette III helicopters. ${ }^{111}$ If we compare this number to the small number of helicopters that the South African military had made available to the Portuguese forces in south-eastern Angola since the end of the 1960s, it is clear that the South African aircraft were not really sufficient to have a significant impact in the overall course of the war in that Portuguese-controlled territory. Moreover, South Africa was also not the origin of most of the military aircraft that the Portuguese used in Africa. During the 1960s and early 1970s, the country that sold the largest number of aircraft to the Portuguese military establishment in Africa was West Germany with over 200 aircraft from 1965 onwards. ${ }^{112}$ By 1973, the Portuguese Air Force had managed to amass a total of 800 aircraft. ${ }^{113}$

The Portuguese Ministry of Finance and the South African Reserve Bank did negotiate a new R150 million loan in March 1974. ${ }^{114}$ The agreement marked a

Alcora Exercise have been declassified. The only available declassified documents are peripheral documents such as agendas of meetings.

110 .P. Cann, Contra-Insurreição em África - O Modo Português de Fazer a Guerra 1961-1974. Edições Atenas, Lda. S. Pedro do Estoril, 1998, p.179.

${ }^{111}$ Ibid.

112 Air Enthusiast - The Historical Aviation Journal, The Portuguese Airforce Since 1912, Issue 73, January and February 1998, pp.31-32. The article mentions that the Portuguese military acquired one dozen Cessna and Piper aircraft from South Africa in the late 1960s. Moreover, the Portuguese also acquired 60 Harvard IIs (T-6C) from South Africa in March 1970.

${ }^{113}$ Ibid, p.32.

${ }^{114}$ AHD, PAA 1140: "Memorial - Assunto: Acordo do empréstimo de 150 milhões de Rands firmado com a R.A.S". from the General Chief of Staff of the Portuguese Armed Forces, Lisbon, 18 September 1975, as well as unsigned and undated topsecret document from Portuguese Minister of National Defence - Lisbon - South African Minister of Defence, Pretoria. A list attached to this document indicates that the loan would be used to buy jeeps, trucks, ammunition, rocket launchers, mortars, 
substantial increase in South Africa's financial exposure in relation to Portugal, especially when compared to the R25 million loan that had clearly disappointed the Portuguese military leadership in 1969. From the perspective of the South African government at the time, the Portuguese military shield in Southern Africa was still viewed as an instrument of regional stability. Otherwise, the loan would not have been granted. It must be pointed out, however, that the new South African loan arrived too late to make any difference to the final outcome of the war in Angola and Mozambique. Although the Portuguese were successful in their attempts to obtain a substantial loan from South Africa, they received only the first instalment of R5 million. ${ }^{115}$ The reason for this was that the South African Reserve Bank suspended the delivery of the remaining instalments after April $1974 .{ }^{116}$ The suspension was caused by the Portuguese revolution of 25 April 1974, which marked the beginning of the process that led to Portugal's withdrawal from Africa. A more successful endeavour was perhaps South African support for the Flechas ${ }^{117}$ - an effective counter-insurgency unit that received semi-automatic rifles from South Africa in the early 1970s. ${ }^{118}$ However, such measures were not sufficient to help change the course of the war in the short term.

One South African official who did not believe that South Africa's commitment to the Portuguese military effort in Africa was sufficient, was the South African Consul General in Luanda, EM Malone. In September 1970, Malone criticised the

machine guns and 20 Mirage V aircraft for the Portuguese Air Force. In addition also see ADN, File 833.9: Document, "Acordo do empréstimo de 150 milhões de Rands firmado com a RAS" by Colonel Francisco de Macedo Magalhães, referring to the loan agreement signed on 8 March 1974, as well as the unsigned and undated top-secret document "Draft - Loan Agreement between the South African Reserve Bank and the Government of the Republic of Portugal".

${ }^{115}$ Ibid.

${ }^{116}$ Ibid.

${ }^{117}$ Ó. Cardoso, Criador dos Flechas in Antunes, J.F. (ed), A Guerra de África (19611974). Vol I. Temas e Debates Lda, Lisboa 1996, pp. 403-405. The person responsible for setting up the Flechas was the Portuguese PIDE Inspector, Óscar de Castro Cardoso, who was trained in internal security and counter-intelligence. The first Flechas units were set up in 1967. These units comprised bush trackers. They were trained in the Missombo camp in Angola's south-eastern Cuando Cubango district.

118 NARS, BTS, Box 1/22/3, Vol 3. Angola: Relations with South Africa. B: 12.06.1970/E: 10.08.1972: Secret letter Consul General, Luanda - Secretary for Foreign Affairs, Pretoria, 19 August 1970. Also see NARS, BTS, Box 1/22/1, Vol 14. Angola: Political Situation and Developments B: 04.01.1971/E: 30.11.1971: Secret letter Consul General, Luanda - Secretary for Foreign Affairs, Pretoria, 25 August 1971. The Flechas also received combat uniforms from South Africa. 
way in which South Africans viewed Portuguese efforts to contain the insurgents in Angola. ${ }^{119} \mathrm{He}$ emphasised that South Africans spoke in a patronising manner about the Portuguese and wrongly believed that South Africans would do better if they were facing the same situation. ${ }^{120}$ In February 1972, Malone said that it was crucial to examine the war in Angola as a whole, and resist the temptation of placing excessive attention on certain events merely because they occurred in areas close to "our own borders". ${ }^{121}$ When he mentioned "our own borders", he was referring to insurgent activity near the border that separated Angola and South West Africa. He explained that the war would be lost or won in the northern and eastern regions of Angola and not in the south. ${ }^{122}$

\section{Conclusion}

Despite the fact that South Africa and Portugal were forced to move closer to one another as a result of the spread of African nationalism and an increasingly hostile international environment during the 1960s, the two countries did not really develop a common political approach that could effectively deal with the perceived threats against the status quo that they wanted to maintain. On the Portuguese side, there was a reluctance to accept a more public and open relationship with South Africa. According to the Portuguese Minister of Foreign Affairs in the early 1970s, Rui Patrício, Portugal would never allow South Africa's direct military intervention in Angola and Mozambique since the Portuguese did not want to compromise their principles. ${ }^{123}$ Furthermore, Patrício confirmed that the Portuguese firmly believed that it was necessary to avoid what he called the "internationalization of the war", which could become a reality if South Africa became directly involved in the counter-insurgency efforts in Angola and Mozambique. He explained that the main objective of Portugal's Ministry of Foreign Affairs was to avoid any gesture that could lead to the escalation of the conflict in the three operational theatres. ${ }^{124}$

In the late 1960s and early 1970s, the South African authorities were increasingly concerned with how the conflict in Angola could affect South West

${ }^{119}$ NARS, BTS, Box 1/22/1, Vol 13. Angola: Political Situation and Developments. B: 05.03.69/E: 21.12.70: Secret letter from Consul General, Luanda - Secretary for Foreign Affairs, Pretoria, 30 September 1970.

${ }^{120}$ Ibid.

${ }^{121}$ NARS, BTS, Box 1/22/1, Vol 15. Angola: Political Situation and Developments, B: 14.12.71/E: 26.09.72: Secret letter from Consul General, Luanda - Secretary for Foreign Affairs, Pretoria, 8 February 1972.

122 Ibid.

${ }^{123}$ R Patrício, Perder na Retaguarda in Antunes, J.F. (ed), A Guerra de África (19611974). Vol II. Temas e Debates Lda. Lisboa 1996, p.1042.

${ }^{124}$ Ibid. 
Africa's northern regions. The focus of South Africa's limited support to the Portuguese in south-eastern Angola was to help prevent security threats in South West Africa. However, in terms of security, south-eastern Angola was not Portugal's main priority. The main concern of the Portuguese military was to ensure the effective control over all of Portugal's geographically vast and separate overseas territories in Africa and Asia. On the African continent, the Portuguese were trying to maintain full military control over three different operational theatres. At the end of 1973, Portugal's military establishment had deployed a total of 150 thousand men in the three operational theatres. ${ }^{125}$ By that time, the Portuguese had been engaged in counter-insurgency operations in Africa for well over a decade. The Portuguese military lost 8290 men in Angola, Mozambique and Guinea Bissau. ${ }^{126}$

South African support could have helped to change the course of the war in the three operational theatres only if such support was made available on a vast and massive scale. This would have to include the provision of additional financial loans as well as the deployment of vast quantities of military equipment and substantial contingents of South African ground forces alongside the Portuguese military forces in the three operational theatres. There is nothing in the available declassified documentation in the Portuguese and South African archives to suggest that Portugal was willing to accept such large-scale South African support or that South Africa was prepared to provide massive aid to the Portuguese military establishment in Africa. What can be said about the relationship between the two countries from the end of the Second World War until 1974 is that it followed an uneven path that was marked by political considerations and self-interest on both sides.

\footnotetext{
${ }^{125}$ Comissão para o Estudo das Campanhas de África, Resenha Histórico Militar das Campanhas de África (1961-1974). Estado Maior do Exército, 1 Vol, 2 Edição Lisboa, p.259.

${ }^{126}$ Ibid, p. 246.
} 